\title{
血球数算定用メランジュールの檢定法 及び各種誤差の推定法
}

\author{
東京医科大学教授 小 宮 悦 造
}

講師宮坂五一郎・雨宮 恒 久・小峰慶三

On the Examination of Blood Diluting Pipettes and the Estimation of Various Errors in the Enumeration of Blood Cells and the Haemoglobinometry

Etsuzo Komiya, Prof. Dr. Med. Tokyo Medical College.

Goichiro Miyasaka, Lecture. Dr. Med. and Dr. Eng. Tokyo Medical College.

Tsunehisa Amemiya, Lecture. Dr. Med. Tokyo Medical College.

Keizo Komine,

Assistant Lecture. Dr. Med. Tokyo Medical College

\section{緒言}

ビキ五問題以来原爆，水爆及びそれらによって生ず る放射性雨や灰等に就て新聞紙上にも大々的に報道さ れ，それらの庋威に対して，国民一般の関心が非常に 高まって来ている.

一方原子力をそ5した破壞的方面にのみ使わず，発 電等に応用し，新らしい動力源として平和的に利用し ようとする企てを各国とす真剣に研究しているから, 近い将来原子力時代の到来することは必至である.

然し原子力を平和的に利用する際でる，必ず放射性 灰等は生ずるのであって，その灰を內輪に見積って も, 年に最小限百トン以上が地上にばらまかれ, 又, 十万キロの原子力発電所を建てると東京都ぐらいの地 域に亘って住民をたちのかせる必要があると云われて いる.

狭い国土に多数の人口をかかえている日本では，来 るぺき原子力時代に於て，その脅威にさらされる事は 世界中で最る大である．従って原子力時代に先だっ て，その放射能症の替威に対して国民の健康を守る手 段が講ぜられなければならない。

一方人体に於て，それら放射線に最る敏感に反応す るるのは血液及び造血組織であるから放射線障害予防 及び早期発見は，血液検査に初まるべきである.

投て正確な血液検査は医師の技術が優秀でなければ ならないことは勿論であるが，同時にその測定器具も 正確でない事には，いくら血液検査を施行してる，斯 界を泿乱させ，患者をまどわすに止まり実際百害あつ て一利もない。

血液学会が, 測定器具の検定に意を用いている所以 も此妈にあるのである。

例えば或る外科手術患者の血色素量が60\%でまった ので輸血及び梖血治療を施したが少しす好転しないの で，他の教室で試みに血色素量正確に測つた所, 100 \%であつて; この患者㤝るとも筫していなかった
とか. 又, 或る病院で白血球を数えた所 3000 以下で大 騒ぎをして心配したが，正確に测った所 5000 で普通 であったとか，当事者にして見れば笑話では済まされ ない閒題が稀れではない，

我々は既に血色素計の検定に就ては本誌 第 24 巻第 10 号に，血球計算板の検定に就ては本誌 第 25 巻 第 1 号に報告したので本号ではメランシュールの検定に就 て述べる.

\section{I ）白血球数算定用メランジュールの梌定}

白血球メランジュールに関する通産省の検定涀格は 第 1 表 白血球メランシュールの検定成續 (1)

\begin{tabular}{|c|c|c||c|c|c|}
\hline No. & $E_{0.5}$ & $E_{1 \cdot 0}$ & No. & $E_{0 \cdot 5}$ & $E_{1 \cdot 0}$ \\
\hline 1 & -3.5 & +0.1 & 21 & -3.5 & -3.1 \\
2 & -1.2 & -1.2 & 22 & -4.5 & -3.2 \\
3 & -2.1 & -1.4 & 23 & -1.4 & -0.9 \\
4 & -1.8 & -1.2 & 24 & -3.8 & -1.7 \\
5 & -2.0 & -0.7 & 25 & -2.0 & -0.7 \\
6 & -2.8 & -2.1 & 26 & -2.5 & -2.0 \\
7 & +0.2 & -1.6 & 27 & -1.1 & -0.8 \\
8 & -1.6 & -0.2 & 28 & -0.8 & -0.2 \\
9 & -1.9 & +2.3 & 29 & -2.9 & -1.5 \\
10 & -2.2 & -0.6 & 30 & -0.9 & -0.7 \\
11 & -1.0 & -1.0 & 31 & -2.0 & -1.4 \\
12 & -1.9 & -0.8 & 32 & -4.7 & -3.1 \\
13 & -3.5 & -2.5 & 33 & +0.7 & +0.1 \\
14 & -3.2 & -2.2 & 34 & -1.9 & -1.5 \\
15 & -2.4 & -2.1 & 35 & -3.2 & -2.1 \\
16 & -1.3 & -0.5 & 36 & -0.8 & -0.4 \\
17 & -2.7 & -1.5 & 37 & -4.9 & -2.8 \\
18 & -1.6 & -0.4 & 38 & -1.8 & -0.8 \\
19 & -1.9 & -1.0 & 39 & -2.3 & -2.0 \\
20 & -3.3 & -2.1 & 40 & -1.7 & -0.3 \\
\hline
\end{tabular}

$\mathrm{E}_{0.5}$ ：膨大部と目盛 0.5 までの容積との比を 20.0 と比較した誤差の\%値

$\mathrm{F}_{1 \cdot 0}$ ：膨大部と目盛 1.0 までの容積との比を 10.0 と比較した誤差の\%值 
士3\%となっているが，これを我々の所で調べて見た 所，この規定は目盛 1.0 までの容積と膨大部の容積に 就いてのみにあてはまり，0.5までの容積に関しては 険定されていないことが分った，それで前者での検定 合格品を，後者で検定して見ると第 1 表に見るよ $3 に$ 大体 1.8 倍程度 (30 本の測定值を比較して), 後者の方 が誤差が大きいことが分ったので，白血球数算定には， 血液を 1.0 すて吸い,特に 0.5 で行万場合には各自で検 定する必要がある，その方法としては

（1）水銀直接秤量洗（2）グリセリン直接秤量沠

(3) Abbe の方法 (後述) 等あるが，ここでは(1)(2) の方法について述へ，之の優劣を比較する.

因みにグリセリンは水より比重が大で蒸発が少く之 にゲンチフナビォレットで着色すれば測定に際して明 瞭に見えて便利である上に後述するような利点があ る.

第 2 表 (1)

白血球メランシュールの検定成樍（2）

\begin{tabular}{|c|c|c|c|c|c|}
\hline 番号 & 方法 & $a-M$ & $C-b$ & $\begin{array}{c}\mathrm{C}-\mathrm{b} / \\
\mathrm{a}-\mathrm{M}\end{array}$ & $\begin{array}{l}\text { 誤差 } \\
\mathrm{E}_{0.5} \%\end{array}$ \\
\hline 1 & $\begin{array}{l}\mathrm{Hg} \\
\mathrm{Gl}\end{array}$ & $\begin{array}{l}0.2278 \\
0.0197\end{array}$ & $\begin{array}{l}4.5114 \\
0.3981\end{array}$ & $\begin{array}{l}19.804 \\
20.208\end{array}$ & $\begin{array}{r}-0.98 \\
+1.04\end{array}$ \\
\hline .2 & $\begin{array}{l}\mathrm{Hg} \\
\mathrm{Gl}\end{array}$ & $\begin{array}{l}0.2280 \\
0.0200\end{array}$ & $\begin{array}{l}4.4572 \\
0.3943\end{array}$ & $\begin{array}{l}19.549 \\
19.715\end{array}$ & $\begin{array}{l}-2.25 \\
-1.43\end{array}$ \\
\hline 3 & $\begin{array}{l}\mathrm{Hg} \\
\text { Gl. }\end{array}$ & $\begin{array}{l}0.2330 \\
0.0206\end{array}$ & $\begin{array}{l}4.5082 \\
0.3991\end{array}$ & $\begin{array}{l}19.348 \\
19.377\end{array}$ & $\begin{array}{l}-3.26 \\
-3.12\end{array}$ \\
\hline 4 & $\begin{array}{l}\mathrm{Hg} \\
\mathrm{Gl}\end{array}$ & $\begin{array}{l}0.2578 \\
0.0225\end{array}$ & $\begin{array}{l}4.9414 \\
0.4354\end{array}$ & $\begin{array}{l}19.167 \\
19.355\end{array}$ & $\begin{array}{l}=4.17 \\
-3.23\end{array}$ \\
\hline 5 & $\begin{array}{l}\mathrm{Hg} \\
\mathrm{Gl}\end{array}$ & $\begin{array}{l}0.2037 \\
0.0179\end{array}$ & $\begin{array}{l}4.0636 \\
0.3601\end{array}$ & $\begin{array}{l}19949 \\
20.117\end{array}$ & $\begin{array}{l}-0.26 \\
+0.58\end{array}$ \\
\hline 6 & $\begin{array}{l}\mathrm{Hg} \\
\mathrm{Gl}\end{array}$ & $\begin{array}{l}0,1538 \\
0.0135\end{array}$ & $\begin{array}{l}3.0355 \\
0.2693\end{array}$ & $\begin{array}{l}19.737 \\
19.948\end{array}$ & $\begin{array}{l}-1.32 \\
-0.26\end{array}$ \\
\hline 7 & $\begin{array}{l}\mathrm{Hg} \\
\mathrm{Gl}\end{array}$ & $\begin{array}{l}0.1493 \\
0.0130\end{array}$ & $\begin{array}{l}2.9234 \\
0.2600\end{array}$ & $\begin{array}{l}19.581 \\
20.000\end{array}$ & $\begin{array}{c}-2.09 \\
0\end{array}$ \\
\hline 8 & $\begin{array}{l}\mathrm{Hg} \\
\mathrm{GI}\end{array}$ & $\begin{array}{l}0.1829 \\
0.0161\end{array}$ & $\begin{array}{l}3.6483 \\
0.3246\end{array}$ & $\begin{array}{l}19.945 \\
20.161\end{array}$ & $\begin{array}{l}-0.28 \\
+0.81\end{array}$ \\
\hline 9 & $\begin{array}{l}\mathrm{Hg} \\
\mathrm{Gl}\end{array}$ & $\begin{array}{l}0.2494 \\
0.0195\end{array}$ & $\begin{array}{l}4.8808 \\
0.3852\end{array}$ & $\begin{array}{l}19.574 \\
19.662\end{array}$ & $\begin{array}{l}-2.13 \\
-1.69\end{array}$ \\
\hline 10 & $\begin{array}{l}\mathrm{Hg} \\
\mathrm{Gl}\end{array}$ & $\begin{array}{l}0.2243 \\
0.0198\end{array}$ & $\begin{array}{l}4.4369 \\
0.4005\end{array}$ & $\begin{array}{l}19.781 \\
20.227\end{array}$ & $\begin{array}{r}-1.09 \\
+1.14\end{array}$ \\
\hline 11 & $\begin{array}{l}\mathrm{Hg} \\
\mathrm{Gl}\end{array}$ & $\begin{array}{l}0.2166 \\
0.0190\end{array}$ & $\begin{array}{l}4.2902 \\
0.3803\end{array}$ & $\begin{array}{l}19.807 \\
20.079\end{array}$ & $\begin{array}{l}-0,97 \\
+0.40\end{array}$ \\
\hline & $\begin{array}{l}\mathrm{Hg} \\
\mathrm{Gl}\end{array}$ & $\begin{array}{l}0.2535 \\
0.0231\end{array}$ & $\begin{array}{l}4.3671 \\
0.3851\end{array}$ & $\begin{array}{l}17.227 \\
16.670\end{array}$ & $\begin{array}{l}-13.87 \\
-16.65\end{array}$ \\
\hline
\end{tabular}

註 1） $\mathrm{Hg}$. Gl. は夫々水銀直接秤量, グリセリン 直接皏量の略

2) *

3） $\mathrm{a}-\mathrm{M}=0.5$ までの水銀又はダリセリンの重 量

4) $\mathrm{C}-\mathrm{b}=$ 膨大部の
第 2 表 (吅)

\begin{tabular}{|c|c|c|c|c|c|c|}
\hline \multirow{2}{*}{ 方法 } & \multicolumn{2}{|c|}{$\begin{array}{l}2 \% \text { 以の俱逵 } \\
\text { そ示ナbの }\end{array}$} & \multicolumn{2}{|c|}{ 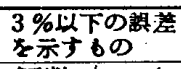 } & \multicolumn{2}{|c|}{ 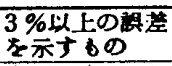 } \\
\hline & 個数 & $\%$ & 個数 & $\%$ & 個数 & $\%$ \\
\hline $\begin{array}{l}\text { グリセ } \\
\text { リン法 }\end{array}$ & $9 / 11$ & 81.8 & $9 / 11$ & 81.8 & $2 / 11$ & 18.2 \\
\hline 水銀法 & $6 / 11$ & 54.5 & $9 / 11$ & 81.8 & $2 / 11$ & 18.2 \\
\hline
\end{tabular}

第 2 表 (N)

\begin{tabular}{|c|c|c|}
\hline & 白血球メラン & $-ル \quad b / a$ \\
\hline 方 & 水銀直接科量 & $\begin{array}{l}\text { グリセリン } \\
\text { 直接种量 }\end{array}$ \\
\hline 平 均 值 & 19.658 & 19.895 \\
\hline 理 想 值 & 20.000 & 20.000 \\
\hline 平均做偏差 & $-1.71 . \%$ & -0.53 \\
\hline 標淮 偏 差 $\sigma$ & 0.244 & 0.320 \\
\hline 修正標準偏差 & 0.545 & 0.320 \\
\hline 変動係数 c.v. & 278 & 1.65 \\
\hline
\end{tabular}

その手拔は

(i) メランシュールのみの重量三M

（ii）目盛り0.5まで水銀又はグリセリンを吸引した ときの重量三a

(iii) " $1.0 \quad$ $\quad \equiv \mathrm{b}$

(iV) $\quad " 11.0$

"I

$\equiv \mathrm{c}$

(V) (ii) より(i)を引いた值三a-M

(iii)より(i)を引いた值三b-M

（Vi）（iV)ょり(iii)を引いた值三cーb

(Vii) (Vi)を(V)で割つた值 即ち $\frac{\mathrm{c}-\mathrm{b}}{\mathrm{a}-\mathrm{M}}=20$, $\frac{\mathrm{c}-\mathrm{b}}{\mathrm{b}-\mathrm{M}}=10$ になれば理想的ヌランシュールであ

る. 第 2 表にその検定成績を示す.

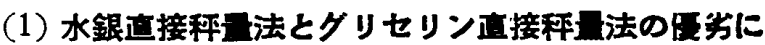
ついては, メランジュールの毛細管に於ては水銀，グ リセリン共に硝子によくなじみ毛細管内を完全に満た すが，膨大部に於ては水銀はその內部に存在する硝子 の小片になじまない為に空間を残す杽念がある。この 事は(i) c-b/a-M の值がグリセリンの方（平均值 19.8 95）が大きく，水銀の方（平均值 19.658）が小さいこ と，(ii)修正䅺淮偏差及変動係数が前者に於て( -0.3 $20 ; \mathrm{C} . \mathrm{V}=1.65)$ 小さく，後者に於て（-0.545;C.V.2.78）で大きいことから,グリセリン法の方が優秀で, 真の值により近い值を示するのと推察される.（iii)但 乙第 2 表の測定成績に於て，水銀法は測定值の変動か 大きい為に 5 回の測定の平均值をとってあるので見挂

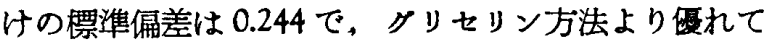
いる様に見えるが，測定回数による修正を施すと 0.545 となり,グリセリン法より大きな值となる.

（2）湌定成繶に硪いて（第 1 表，第 2 表参考） 
（）目盛り 0.5 までの容積と膨大部との容積比

$$
c-b / a-M
$$

理想值は20.0であるが，検定した製品では，その平 均值 $=19.63$ 誤差 $=-1.83 \%$ 標淮偏差 $=0.308$ 変動 俰数 $=1.54 \%$ 誤差 $2 \%$ 以內によるもの $58 \%, 3 \%$ 以內 のもの $73 \%$ 従って検定済のものにして $3 \%$ を超える るのが $27 \%$ ああり無銘品には $10 \%$ 以上の誤差を示す あのがあることは注意すべきである。

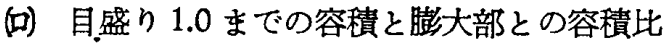
$c-b / b-M$

理想值は 10.0 で検定製品の平均値 $=9.87$ 誤差 $=$ $-1.3 \%$ 標隻偏差 $=0.105$, 変動係数 $=1.06 \%$ 誤差

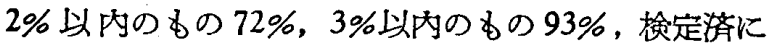
して3\%を超えるもの 7\%程度あり注意すべきである.

\section{II）赤血球用メランジュールの検定}

通産省の検定規格は土 $6 \%$ であるので，我々はこれ をさ3\%にする様陳情したが，現在はそのまつになっ ているので, 精密な䄼查の場合には各自で検定するよ り他はない。

最近業者が持参した製品を検定した結果を第 3 表に 示す. 白血球と違い 1.0 をでの容積と脰大部の容積の 比でも，0.5 そでの容積と膨大部の容積の比でも両者の

第3表 赤血球メランシュュールの検定成績 (1)

\begin{tabular}{|c|c|c||c|c|c|}
\hline No. & $\mathrm{E}_{0 \cdot 5}$ & $\mathrm{E}_{1 \cdot 0}$ & No. & $\mathrm{E}_{0 \cdot 5}$ & $\mathrm{E}_{1 \cdot 0}$ \\
\hline 1 & -1.4 & -1.3 & 21 & +0.4 & -0.2 \\
2 & +1.0 & +0.2 & 22 & -1.7 & -1.8 \\
3 & +1.8 & +0.9 & 23 & +3.4 & +0.2 \\
4 & -1.0 & -1.3 & 24 & -0.4 & -0.9 \\
5 & -1.6 & -1.3 & 25 & +0.4 & -0.6 \\
6 & -0.7 & -0.5 & 26 & -0.9 & -0.6 \\
7 & -0.4 & -1.1 & 27 & +0.4 & -1.1 \\
8 & +0.2 & -0.8 & 28 & -0.9 & -0.4 \\
9 & -1.6 & -1.7 & 29 & -1.5 & -1.0 \\
10 & -1.5 & -1.4 & 30 & -0.4 & -0.4 \\
11 & +0.1 & -0.4 & 31 & -0.7 & -0.8 \\
12 & +1.4 & +0.2 & 32 & -2.1 & -1.5 \\
13 & +2.2 & -0.1 & 33 & +0.1 & -0.5 \\
14 & -0.1 & -0.3 & 34 & -1.2 & -0.5 \\
15 & -1.5 & -0.9 & 35 & +0.7 & +0.1 \\
16 & +0.5 & -1.1 & 36 & -0.9 & -1.1 \\
17 & +2.2 & +0.6 & 37 & +0.4 & -0.5 \\
18 & +0.1 & +0.4 & 38 & -0.6 & -0.6 \\
19 & $+0,6$ & -0.2 & 39 & -1.4 & -1.3 \\
20 & -1.1 & -1.1 & 40 & -0.2 & -0.8 \\
\hline
\end{tabular}

$E_{0.5}$ ： 膨大部と目盛 0.5 までの容積との比を 200,0 と比較した誤差の\%値

$E_{1 \cdot 0}$ ：膨大部と目盛 1.0 までの容積との比を 100.0 と比較した誤差の\%值
誤差の間に余り違いはない様である.

方法としては，このメラシジュールは毛細管部が極 めて細い上に，グリ゙せンは粘稠度が高く吸引か困難 で，赤血球用メランシュールの検定には用いられない ので，次に述べる方法を用いた（1）水銀時計血法及 び(2)アッべ法（メランジュールの毛細管部に水銀， 膨大部に水を充す方法）を行った。

（1）水銀時针血法は前述の水銀直接秤量法と大体同 じであるが，唯次の二点が異る.

(個々のメランジュールの重量を秤る代りに時計四 の重量を秤る，これは秤量回数を少なくする便利 がある。

(吔吸引した水銀は時計血の上に排出して重量を秤 ๖.

尚一般に水銀を用いる方法はメランシュュ 一ルの目盛りまで正確に吸引忖る事が難し く，それによって生ずる誤差のために，鬼 角精度が悪い様に云われているが，後述す る第1図のよ5なスポイトを用いれば容易 に而も正確に目盛りに一致させることが出 来る.

（2）Abbe の方法は (1)容積比で(吅㸝大部 を水銀の代りに蒸溜水で充し，水銀の前述 の矢点を補 5 点で前者より優れている.こ の方法は後述する如く他の方法に比して最 も正確であるからだれでも実施出来る様に その手技を詳しく具体的に述べて見上う。

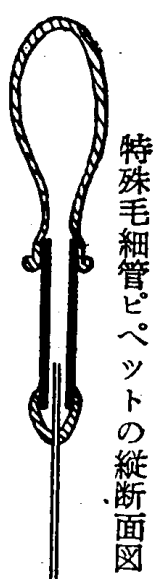
附）水のみで检定を行了時は天科の精度が 影響して，正確に拜量出来ない為に誤差を 生ずる. Abbe の方法水水銀と水との併用 に妙味がある，又分銅の補正も一広考量す る必要がある。

(イ双て Abbe の方法に使う水銀は精製し たるの，蒸溜水は一度煮沸したものを用い，共に前日 から天秤室に置いて室温と同温度にしておく，因みに メランジュールは予めクローム硫酸て清净する. それ には吸いゴム管をメランジュールの先端につけ，メラ ンシュールの展からクローム䟽酸を吸 5 と抵抗が少く 容易にメランジュールを充すことが出来る。クローム 硫酸を充したるのは大型のシャーレまたは試験管に入 れて一昼夜拉く，急ぐ場合には温めると数十分で清浄 となる，それから水で洗い，型の如くアルコールと工 一テルとを通して譤燥し，天秤公にしばらく置いて室 温と同温度とする．次に水銀をメランジュールの細管 部の劃線まで吸い上げるには，我々が考案した毛細管 ピペットを用いると容易に，而も正確に行うことが出 来る.

(只毛細管ピペットの作り方=ガラス管をブンゼン登 で烤いて引き伸し，赤血球用或は白血球用メランシュ 一ルの細管部に夫々自由に挿入し得るよ5な毛細管を 作る.これを約 $12 \mathrm{~cm}$ の長さに切る. 近頃メランジ ールを新らしく買らと先端を保護するために，ゴム製 
の小キャップがついているが，このキャップの先に針 で孔を空け，前述のガラス毛細管を約 $1 \mathrm{~cm}$ 剌し込む。 次に外径約 4 5 $\mathrm{mm}$ のガラス管を約 $2 \mathrm{~cm}$ の長さに切 りそその一端に前述の毛細管の刺してある小キ+ップ を被せる．他端に駒込ピペットに用いる普通のゴムキ トップを附ける.（第1 図参炤）

(り毛細管ピペットの使い方＝先づ空のメランシュー ルの重量 (M)を量る。次に劃線 0.5 まで水銀を充した まつのメランジュールの重量（a）を量る。この場合水 銀は長さ $5 \mathrm{~cm}$ 程の小試験管に約 $0.5 \mathrm{cc}$ 入れて扣き， 邓 ランシュールを注よ゙水平に保ちながら水銀を画線より 少し多めに吸い上げる．次にメランジュールを水平に 保ったまらで，試験管の外に出し，メランシュールの 先端を左手の拇指の腹で押党，示指と中指で管部を挾 んで垂直に立てる．次に吸ゴム管を外して前述の特製 毛細管ピペットをメランジュールの尻から捅入し, 過 剩の水銀を吸い取って水銀精を正確に画線に一致させ て後，静かに天科の血の上に載せて量る．同様にして 水銀を画線 1.0 まで充たしたままのメランジェールの 重量 (b)を量る．次に水銀を残りなく吹き出し，蒸溜 水を膨大部の上の画線まで充たしてその重量 (C)を量 る. 以上により秤量は終る. 次に容積比を計算する。 それ忙基準温度 $15^{\circ} \mathrm{C}$ 亿対する水銀，水及びガラス 器の温度による膨脹を次の計算式により補正し, メラ ンシュール內腟の各画線までの真の容積を求めねばは らない。

(二量容器容積の温度による補正式

度量衡施行 細則によれば量容器の基準温度は $15^{\circ} \mathrm{C}$ であるから, 量容器, 外気及び水又は水銀の夫々の温 度が $15 \mathrm{C}$ である場合の標識線まで満たす水又は水銀 の重量を $15^{\circ} \mathrm{C}$ の水の密度で割つた值が量容器の真の 容積である. 然し容器, 外気, 水 (水銀) の温度を常 に $15^{\circ} \mathrm{C}$ に保つことは常用的不可能であるから, 容 器及び水（水銀）の温度による䁗脹等を考慮して修正 せねばならない，水銀及び水に対する補正係数は次の 梯にして求められる。

記号

$\mathrm{Pt}, \mathrm{P}$ Hgt, $=\mathrm{t}^{\circ} \mathrm{c}$ の室温に於て天秤で水銀と分銅と が釣合った場合の分銅及び水銀の重量.

$\mathrm{Pt}, \mathrm{P}$ Hgt, $\mathrm{Pot}=\mathrm{t} \mathrm{c}$ 火於忛 る分銅 $\left(\mathrm{P}_{15}=8.4\right)$, 水銀 $\left(\mathrm{P}_{\mathrm{Hg}} \mathrm{H}_{15}=13.5585\right)$ 及び水 $\left(\mathrm{Po}_{15}=0.99913\right)$ の密度

$\mathrm{V}_{15}=$ 基準温度 $15^{\circ} \mathrm{C}$ に於ける量容器の真の容積.

$\mathrm{Vt}=\mathrm{t}^{\mathrm{c}} \mathrm{c}$ に於故る量容容の見挂けの容皘.

$\alpha_{\mathrm{Hg}}, \alpha_{0}=$ 水銀及び水の体膨脹保数 $(\alpha \mathrm{hg}=0.1818 \times$

$10-3) \quad(\alpha 0=0.150 \times 10-3) \quad\left(\right.$ 但し $10 \sim 20^{\prime} \mathrm{c}$ ) $\beta=$ 硝子 $\left(1+16^{\prime \prime \prime}\right)$. の線膨脹俰数 $=0.081 \times 10^{-4}$ $\lambda \mathrm{t}=$ 空気の密度 $\left(15^{\circ} \mathrm{C} 760 \mathrm{mmHg}\right.$ 湿度 $80 \%$ に対 して $1.226 \times 10^{-3} \mathrm{~g} / \mathrm{cm}^{3}$ )

○水銀に対する補正係数 $\mathrm{K}_{\mathrm{Hgt}}$;

天秤の釣合いの式

$$
\left(P_{H g t}-\frac{P_{H g t}}{P_{H g t}} \lambda t\right)=\left(P t-\frac{P_{t}}{P_{t}} \lambda t\right)
$$

一方 $P_{\text {Hgt }}=$ Vt PHgt $_{\text {H }}$

$\mathrm{Vt}=\mathrm{V}_{15}[1+3 \beta(\mathrm{t}-15)]$

$\mathrm{P}_{\mathrm{Hgt}}=\mathrm{P}_{\mathrm{Hg}} \mathrm{I}_{16}[1-\alpha \mathrm{Hg}(\mathrm{t}-15)]$

以上の 4 つの式より

$$
\begin{aligned}
& V_{15}=\frac{\operatorname{Pt}\left(1-\frac{\lambda t}{\mathrm{Pt}}\right)}{\operatorname{PHg}_{15}\left(1-\frac{\lambda t}{P_{H g t}}\right)} . \\
& \frac{1}{[1+3 \beta(t-15)][1-2 \mathrm{Hg}(\mathrm{t}-15)]}=\mathrm{PtK}_{\mathrm{Hg}} \\
& \mathrm{KHg} \div \frac{\mathrm{Pt}}{\mathrm{PHg}_{15}}\left[1+(\alpha \mathrm{Hg}-3 \beta)(\mathrm{t}-15)-\left(\frac{1}{\mathrm{pt}}-\right.\right. \\
& \left.\left.\frac{1}{P_{\text {Hgt }}}\right) \lambda t\right]
\end{aligned}
$$

\begin{tabular}{|c|c|c|c|c|c|}
\hline $\mathrm{t}^{-\mathrm{C}}$ & $\begin{array}{c}\text { 水 } \\
\left(\mathrm{KH}_{2} \mathrm{O}\right)\end{array}$ & $\begin{array}{l}\text { 水銀 } \\
\text { (KHg) }\end{array}$ & $t^{\circ} \mathrm{C}$ & $\left(\begin{array}{c}\text { 水 } \\
\left(\mathrm{K}_{2} \mathrm{O}\right)\end{array}\right.$ & $\begin{array}{l}\text { 水銀 } \\
(\mathrm{KHg})\end{array}$ \\
\hline 0 & 1.0016 & 0.07357 & 18 & 1.0024 & 0.07378 \\
\hline 1 & 15 & 59 & 19 & 25 & 80 \\
\hline 2 & 14 & 60 & 20 & 27 & 81 \\
\hline 3 & 14 & 61 & 21 & 29 & 82 \\
\hline 4 & 14 & 63 & 22 & 31 & 83 \\
\hline 5 & 13 & 64 & 23 & 33 & 84 \\
\hline 6 & 13 & 65 & 24 & 35 & 85 \\
\hline 7 & 14 & 66 & 25 & 37 & 86 \\
\hline 8 & 14 & 67 & 26 & 40 & 88 \\
\hline 9 & 14 & 68 & 27 & 42 & 89 \\
\hline 10 & 15 & 70 & 28 & 45 & 90 \\
\hline 11 & 15 & 71 & 29 & 47 & 91 \\
\hline 12 & 16 & 72 & 30 & 50 & 92 \\
\hline 13 & 17 & 73 & 31 & 53 & 93 \\
\hline 14 & 18 & 74 & 32 & 56 & 94 \\
\hline 15 & 19 & 75 & 33 & 59 & 96 \\
\hline 16 & 21 & 76 & 34 & 62 & 97 \\
\hline 17 & 22 & 77 & 35 & 66 & 98 \\
\hline
\end{tabular}

同様にして水に対する補正係数 $\mathrm{K}_{\mathrm{H}_{2}} \mathrm{o.t}$;

第4表 ガラス器に盛つた水または水銀の見掛けの 重量より $15^{\circ} \mathrm{C}$ に淤けるガラス器の內容を 計算するために乗ずべき係数 
$\mathrm{KH}_{2} \mathrm{O}=\left[1+(\alpha \mathrm{ot}-3 \beta)(\mathrm{t}-15)-\left(\frac{1}{\mathrm{Pt}}-\frac{1}{\mathrm{Pot}}(\lambda \mathrm{t}]\right.\right.$ 上式を略算し表にすれば第4 表が得られる.

（村）真の容積比は，上表を参考にして次の様にして求 められる.

即ち，劃線 0.5 までの容積と膨大部の容積との比は $\mathrm{co} / \mathrm{A}=\left[(\mathrm{C}-\mathrm{M}) \mathrm{K}_{\mathrm{H}_{2} \mathrm{Ot}}-(\mathrm{b}-\mathrm{M}) \mathrm{K}_{\mathrm{Hgt}}\right] /(\mathrm{a}-\mathrm{M})$ $\mathrm{K}_{\mathrm{H}} \mathrm{gt}$ この值を 200 と比較し,

\section{第 5 表 (1)}

赤血球メランシュールの検定成樍 (2)

\begin{tabular}{|c|c|c|c|c|c|}
\hline 番号 & 方法 & 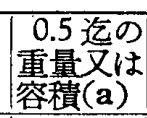 & 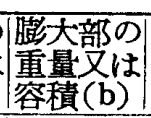 & $\mathrm{b} / \mathrm{a}$ & 誤 差 \\
\hline 1 & $\begin{array}{l}\mathrm{Hg} \\
\text { Abbe }\end{array}$ & $\begin{array}{l}0.0791 \\
0.00583\end{array}$ & $\mid \begin{array}{c}15.8441 \\
1.16497\end{array}$ & & \\
\hline 2 & $\begin{array}{l}\mathrm{Hg} \\
\text { Abbe }\end{array}$ & $\mid \begin{array}{l}0.0579 \\
0.00427\end{array}$ & $\left|\begin{array}{c}11.3604 \\
0.84133\end{array}\right|$ & & \\
\hline 3 & $\begin{array}{l}\mathrm{Hg} \\
\text { Abbe }\end{array}$ & $\begin{array}{l}0.0632 \\
0.00466\end{array}$ & $\left|\begin{array}{c}12.5442 \\
0.92614\end{array}\right|$ & & $\begin{array}{l}-0.77 \\
-0.63\end{array}$ \\
\hline 4 & $\begin{array}{l}\mathrm{Hg} \\
\text { Abbe }\end{array}$ & \begin{tabular}{|l|}
0.0664 \\
0.00489 \\
\end{tabular} & $\left|\begin{array}{r}13.2000 \\
0.97446\end{array}\right|$ & & $\begin{array}{l}-0.60 \\
-0.47\end{array}$ \\
\hline 5 & $\begin{array}{l}\mathrm{Hg} \\
\text { Abbe }\end{array}$ & $\begin{array}{l}0.0751 \\
0.00553\end{array}$ & $\begin{array}{c}14.8825 \\
1.09798\end{array}$ & & \\
\hline 6 & $\begin{array}{l}\mathrm{Hg} \\
\text { Abbe }\end{array}$ & $\mid \begin{array}{l}0.0557 \\
0.00411\end{array}$ & \begin{tabular}{|c|}
11.0305 \\
0.81390
\end{tabular} & & \\
\hline 7 & $\begin{array}{l}\mathrm{Hg} \\
\text { Abbe }\end{array}$ & $\begin{array}{l}0.0592 \\
0.00436\end{array}$ & \begin{tabular}{|r|}
11.5961 \\
0.85490
\end{tabular} & & \\
\hline 8 & $\begin{array}{l}\mathrm{g} \\
\text { bbe }\end{array}$ & $\begin{array}{l}0.0668 \\
0.00493\end{array}$ & $\mid \begin{array}{c}13.0693 \\
0.96667\end{array}$ & & \\
\hline 9 & $\begin{array}{l}\mathrm{Hg} \\
\text { Abbe }\end{array}$ & $\begin{array}{l}0.0584 \\
0.00431\end{array}$ & $\left|\begin{array}{c}11.5816 \\
0.85720\end{array}\right|$ & & \\
\hline 10 & $\begin{array}{l}g \\
b b e\end{array}$ & $\left|\begin{array}{l}0.0549 \\
0.00405\end{array}\right|$ & $\left|\begin{array}{c}10.8004 \\
0.79783\end{array}\right|$ & $\begin{array}{l}196.72 \\
196.98\end{array}$ & \\
\hline 11 & & $\begin{array}{l}0.0348 \\
0.00273\end{array}$ & $\begin{array}{l}6.9823 \\
0.51650\end{array}$ & & \\
\hline 12 & & & $\begin{array}{l}8.1559 \\
0.60572\end{array}$ & & \\
\hline 13 & & \begin{tabular}{l|l|}
0.0383 \\
0.00283
\end{tabular} & & & \\
\hline 14 & & \begin{tabular}{|l|}
0.0392 \\
0.00289
\end{tabular} & $\begin{array}{l}7.6521 \\
0.56625\end{array}$ & $\begin{array}{l}195.20 \\
195.92\end{array}$ & \\
\hline 15 & & \begin{tabular}{|l|}
0.0372 \\
0.00275
\end{tabular} & $\begin{array}{l}7.3410 \\
0.54282\end{array}$ & & \\
\hline 16 & & & $\begin{array}{l}7.5831 \\
0.56097\end{array}$ & $\begin{array}{l}196.45 \\
196.83\end{array}$ & $\begin{array}{l}-1.88 \\
-1.58\end{array}$ \\
\hline * & & 1586 & 10.3295 & 176.27 & -11 \\
\hline
\end{tabular}

註 1) $\mathrm{Hg}$, Abbe は夫々水銀時計血法, Abbe 9 方法の略

2）Abbe の方法の際には (a)，(b)は共に容積を とる

3) * は無銘品
第 5 表 (可)

\begin{tabular}{|c|c|c|}
\hline & \multicolumn{2}{|c|}{ 赤血球メランシール b/a } \\
\hline 方法 & 水銀時計血法 & Abbe の方法 \\
\hline 平 均 值 & 197.83 & 198.27 \\
\hline 理 想 傎 & 200.00 & 200.00 \\
\hline 平均值偏差 & $-1.13 \%$ & $-0.86 \%$ \\
\hline 相淮偏差 a & 1.77 & 1.53 \\
\hline 変動係数 c.v & 0.89 & 0.77 \\
\hline
\end{tabular}

また，劃線 1.0 までの容積と䞘大部の容積との比は $\mathrm{C} / \mathrm{B}=\left[(\mathrm{C}-\mathrm{M}) \mathrm{K}_{\mathrm{H}_{2}} \mathrm{Ot}-(\mathrm{b}-\mathrm{M}) \mathrm{K}_{\mathrm{Hgt}}\right] /(\mathrm{b}-\mathrm{M})$ $\mathrm{K}_{\mathrm{Hgt}}$ この值を 100 と比較して, 夫ょの誤差を求めれ ば良い。

( 検定成績を第 5 表に示す

（1）水銀時計皿法と Abbe の方法の優劣.

(i) C-b/a-M 又は C/A の值力前者の方 (平均值 =197.83）か後者（平均値=198.27）上りも常に 小さい．このことは水銀は膨大部を完全に満さな い恐れのあることを示す。

(ii) 標準偏差, 変動俰数は前者の方か（ $\sigma=1,77$ C. $\mathrm{V}=0.89$ 後者 $(\sigma=1.53 \mathrm{C} . \mathrm{V}=0.77)$ 上りあ大 きい.

これ等の事から Abbe の方法が優れていると云い得 る.

（2）湌定成栍に就いて（第 3 表，第 5 表参照)

(イ目盛り 0.5 までの容積と膨大部との容積比 C/A 理想値は 200.0 検定製品の平均値 $=198.88$

誤差 $=-0.56 \%$, 標準偏差 $=1.96$, 夜動俰数 $=0.99 \%{ }^{\circ}$ 誤差 2\%以内にあるすの $90 \%$ 3\%以内の 3\%を超えるすのは 4\%程度である. 無銘品には $12 \%$ のものがある注意すべきである.

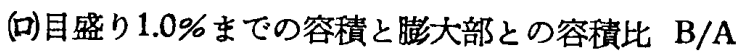
理想值は 100.0 検定製品の平均値 $=99.38$

誤差 $=-0.62 \%$, 標準偏差 $=0.41$, 変動保数 $=0.42 \%$ 製品(40個)の全部か䛇差 $2 \%$ 以内にあり非常に傮秀で ある. 後述する如く誤差の推定計算より, 我々は検定 標準を2\%又は3\%に引上げることを提唱しているが， この提案む決して無理な要求でないこともこの事実か ら証明される. 但し無銘品には $10 \%$ 以上の誤差を示 すあのがある.この事拜入に際して注意すべきであ る. 㑇毛細管が太きに過ぐれば血液又は混合液が落下． し，誤差が大きくなり，細きに過ぎれば血液が凝固し 易いと云り事実がある。

（3）秤具法によらない他の方法として発色性の液体を 
各劃線まで充たし，之を適当に稀釈して光電比色計で 吸光度を比較する方法すあるか，光電比色計の精度と 途中の操作による誤差か問題であって (1)（2）の种量 法に劣ると思われる。

\section{III) 誤差の推定法}

以上により血色素計，血球計算板及び各種メランジ ュールの検定法，市販製品の精度を論じたのである が, 次にこれらの血液測定器具を用いて測定した值に はどれ程の誤差が見積られるかを述へて見よう。

(1) 血球数に對する畧差推定式

次式は $1 \mathrm{~mm}^{3}$ の血液中に含まれる白血球数 $\mathrm{Nw}$ 、及 び赤血球数 $\mathrm{N}_{\mathrm{R}}$ に対する算定式である.

$$
\mathrm{N}=\mathrm{n} \times \frac{1}{\mathrm{~d}_{1}} \times \frac{1}{\mathrm{Z} \times \mathrm{d}_{2}{ }^{2}} \times \mathrm{d}_{3}
$$

但し $\mathrm{N}=1 \mathrm{~mm}^{3}$ の血液中に含まれる血球総数

$\mathrm{n}=$ 計算板の目盛面に於て，Z小区劃内に含まれ る血球数

（顥微鏡下に於て数えられた血球数）

$Z$ =血球数を数えるべき小区劃 $(0.05 \mathrm{~mm})^{2}$ 又は $(1.0 \mathrm{~mm})^{2}$ の数

$\mathrm{d}_{1}$ =計算板の平均の深さ $=0.100 \mathrm{~mm}$

$\mathrm{d}_{2}=$ 標線目盛間漂 $(0.05 \mathrm{~mm}$ 又は $1.0 \mathrm{~mm})$

$\mathrm{d}_{3}=$ 血球用メランジュールの稀釈倍数

(1) より $\log \mathrm{N}=\log \mathrm{n}-\log \mathrm{d}_{1}-\operatorname{long} \mathrm{z}-2 \log \mathrm{d}_{2}$

$$
+\log \mathrm{d}_{3}
$$

微分して $\frac{\Delta \mathrm{N}}{\mathrm{N}}=\frac{\Delta \mathrm{n}}{\mathrm{n}}-\frac{\Delta \mathrm{d}}{\mathrm{d}_{1}}-2 \frac{\Delta \mathrm{d}_{2}}{\mathrm{~d}_{2}}+\frac{\Delta \mathrm{d}_{3}}{\mathrm{~d}_{3}}$

であるから

$\frac{\Delta \mathrm{N}}{\mathrm{N}}=$ 算定された血球数の総誤差

$\frac{\Delta \mathrm{n}}{\mathrm{n}}=$ 顕改鏡下で実際に数える血球数による誤差

$=\frac{1}{\sqrt{\mathrm{N}}}$

（但し誤差論上 $\Delta \mathbf{n} \div \sqrt{\mathbf{n}}$ と見做される）

$\frac{\measuredangle \mathrm{d}_{\mathrm{l}}}{\mathrm{d}_{1}}=$ 計算板の深さによる誤差

$\frac{\Delta \mathrm{d}_{2}}{\mathrm{~d}_{2}}=$ 計算板の標線間隔による誤差

$\frac{\Delta \mathrm{d}_{3}}{\mathrm{~d}_{3}}=$ メランジュールの稀积倍数の誤差

$\alpha=$ 測定個人差による誤差

とすれば

$$
\frac{\Delta \mathrm{N}}{\mathrm{N}}=\frac{\Delta \mathrm{n}}{\mathrm{n}}-\frac{\Delta \mathrm{d}_{1}}{\mathrm{~d}_{1}}-2 \frac{\Delta \mathrm{d}_{2}}{\mathrm{~d}_{2}}+\frac{\Delta \mathrm{d}_{3}}{\mathrm{~d}_{3}}+\alpha
$$

従って推定されるべき誤差として現在の製品及び計算 方法に従えば
(1) 白血球数に対して

$$
\frac{\Delta \mathrm{n}}{\mathrm{n}}=\frac{1}{\sqrt{300}} \fallingdotseq 6 \%
$$

但しメランシュールの稀釈倍数に関係なく顕砫鏡下で 300 個程度を数えるすのとする.

$$
\frac{\Delta \mathrm{d}_{1}}{\mathrm{~d}_{1}}= \pm 3 \% \quad \frac{\Delta \mathrm{d}_{2}}{\mathrm{~d}_{2}}= \pm 0.2 \% \quad \frac{\Delta \mathrm{d}_{3}}{\mathrm{~d}_{3}}= \pm 3 \%
$$

故比 $\left[\frac{\Delta \mathrm{n}}{\mathrm{n}}\right]_{\max }=6.0+3.0+0.4+3.0 \div 12.5 \%$

か推定されるべき最大誤差である。な和前述した如く 白血球用メランシュールは 0.5 区劃まで吸った場合は 器具の誤差が大きいから，1.0区劃をで吸ら方が良い。

(句赤血球数に刘して

$$
\begin{aligned}
& \Delta \mathrm{n}=\frac{1}{\sqrt{\mathrm{n}}}=\frac{1}{\sqrt{500}}=4.5 \% \\
& \frac{\Delta \mathrm{d}_{1}}{\mathrm{~d}_{1}}= \pm 3 \% \cdot \frac{\Delta \mathrm{d}_{2}}{\mathrm{~d}_{2}}= \pm 0.2 \%
\end{aligned}
$$

$\frac{\Delta \mathrm{d}_{3}}{\mathrm{~d}_{3}}$ に関しては検定規格は土6\% となっているか． 誤差論の立場からは, 測定器具による誤差項 $=\frac{\Delta \mathrm{d}_{1}}{\mathrm{~d}_{1}}+$ $2 \frac{\Delta \mathrm{d}_{2}}{\mathrm{~d}_{2}}-\frac{\Delta \mathrm{d}_{3}}{\mathrm{~d}_{3}}$ は計算による誤差 $=\frac{\Delta \mathrm{n}}{\mathrm{n}}$ より小又は精々同 程度である事が望ましい，従って $\frac{\Delta \mathrm{d}_{3}}{\mathrm{~d}_{3}}= \pm 6 \%$ はこの 見地からあ不適である. 即ち少くとも $\frac{\Delta \mathrm{d}_{3}}{\mathrm{~d}_{3}}= \pm 3 \%$ あるべきであり，この提案は第 3 表及び第 5 表の検定 成績からす決して無理ではない。

㓞て $\frac{\Delta \mathrm{d}_{3}}{\mathrm{~d}_{3}}= \pm 3 \%$ とすれば

$$
\left[\frac{\Delta \mathrm{N}}{\mathrm{N}}\right]_{\max }=4.5 \%+3 \%+0.4 \%+3 \% \div 11 \%
$$

が推定される最大誤差である.

(ソ)なお血球数の誤差に関しては上述の如く $\frac{\Delta \mathrm{n}}{\mathrm{n}}=$ $\frac{1}{\sqrt{\mathrm{n}}}$ 項が決定的役割を示すからこれについて少しく述 べて見よ5，即ち顕微鏡下で血球数を一体何個又は何 区劃数えれば良いか．更に何個数えればどの程度の誤 差が生ずるかに就いて樼々質間を受けるが、これに関 しては誤差論的に次の第6表に示す様な関係がある. (この表は白, 赤血球数に共通に使用される。これに よれば数える血球数が1000個の場合には計数による誤 差は土3.2\% 500個の場合には士4.5\%になり，300個以 下では誤差が大きくなりその意義が失はれる. 従って 赤血球に対しては象す角として白血球に対してす 300 個以上を数えることを拉すすめする. 150 個程度では $8.5 \%$ 程度の誤差を生ずることは鉻記すべきである。

第 6 表

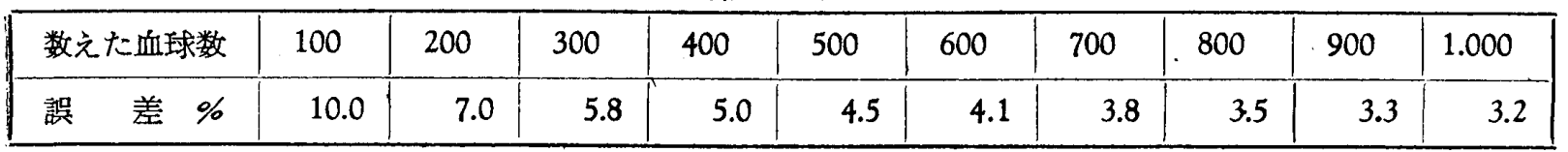


頚血又は白血球減少症の場合でも数学るべき数は， 同数であり唯その場合は区劃数 $Z$ を増す必要がある. 血球の実数は，算定式(1)より換算すれば良い。

\section{(2) 血色暴計の證美の推定}

衆知の如くザーリ血色素計は正常健康人血液 (1 d に凡そ $16.0 \mathrm{gr}$ のへモグロビンを含む)を $20 \mathrm{cmm}$ 採血 し，それを $0.1 \mathrm{~N}$ 塩酸で約 100 倍に薄めて作った塩酸 へマチン液の色調を基準色ガラス棒又は板と比色し等 色になったときの読みは大体 100\% となる。この関係 を式で表はせば

$$
\alpha . \beta \text { ' } \gamma . \mathrm{k}=\mathrm{H}
$$

但し $\alpha=$ 測定すべき人血のへモグロビン量 $\div 16 \mathrm{gr} / \mathrm{dl}$ $\beta=$ ピペットで採取すぺき量 $\div 20 \mathrm{cmm}$ $\gamma=$ 稀釈に要した $0.1 \mathrm{~N}$ 塩酸の量 $\div 2.0 \mathrm{cc}$ $\mathrm{H}=$ 標準塩酸へマチン溶液の色調 (色彩学的要素) $\mathrm{k}=$ 比例常数

従って $\log \mathrm{d}=\log \mathrm{H}-\log \beta-\log \gamma-\log \mathrm{k}$

微分して $\frac{\Delta \alpha}{\alpha}=\frac{\Delta \mathrm{H}}{\mathrm{H}}-\frac{\Delta \beta}{\beta}-\frac{\Delta \gamma}{\gamma}$

但し $\frac{\Delta \alpha}{\alpha}=$ ザーリ血色素計の読みの誤差

$\frac{\Delta \mathrm{H}}{\mathrm{H}}=$ 㙁酸へマチン溶液に対して標準色硝子板又は

棒の誤差と肉眼的比色による誤差とを合せた誤差。

$\frac{\Delta \beta}{\beta}=$ 搡血用ピペットの誤差

$\frac{\Delta \gamma}{\gamma}=$ 目盛り試験管の誤差

一方 $\frac{\Delta \mathrm{H}}{\mathrm{H}}$ に関する我々の研究によれば

同一熟練者が用いた場合 $\frac{\Delta \mathrm{H}}{\mathrm{H}}=1.82 \%$

內科医局員少＂＂＝2.99\% 全科医局員か＂ｌ＝4.69\%

である. 従つて $\frac{\Delta H}{H}=3 \%$ 見積れば

$\frac{\Delta \beta}{\beta}+\frac{\Delta \gamma}{\gamma} \div 3 \%$ 程度に収める事が望ましい。

ピペットに標識線をつけることは正確な目盛り試験

管を作ることより簡単且つ容易であるから

$$
\frac{\Delta \beta}{\beta} \div 1 \% ; \frac{\Delta \gamma}{\gamma} \div 2 \%
$$

が一応の検定基準となる，又この実施は我々の今迄の 検定成績から見てる難事ではない。

以上の様な検定基準では血色素計の最大推定誤差は

$$
\left[\frac{\Delta \alpha}{\alpha}\right]_{\max } \div 6 \% \text { よる。 }
$$

\section{結語}

(1) 白血球用メランジュールの検定規格士 $3 \%$ 目盛 り 1.0 までの容積と膨大部の容積に関するるので, 目盛 り 0.5 までの容積については誤差は大きく, 従って白 血球数算定には後者を用いない方が良い．

（2）水銀法とグリセリン法とを比較し，後者の方が簡 単で精度が高い. 白血球用メランジュールの険定には この方法を持す〉めする。

(3) 赤血球用メランジュールの険定規格士 $6 \%$ 早急 に土 $3 \%$ 改正すべきである.

（4）水銀法とAbbe の法とを比較し、後者が優れてい

る. その検定手技に就いて詳述した。

（5）白血球数の最大推定誤差は土 $12.5 \%$, 赤血球数の それは士11\%で，計算による誤差がそれらの半分を占 めるから，標淮値等を定める精密な検査には，白血球 数は約 500 , 赤血球数は約 1000 個を計数する事か望ま しい. 血色素計の最大推定誤差は土 $6 \%$ である.

\section{読 者 の 馨}

るすてのしてご全起結をにに粗湯をす無のた上仕つの呑が意れ集ばた間のた識招御

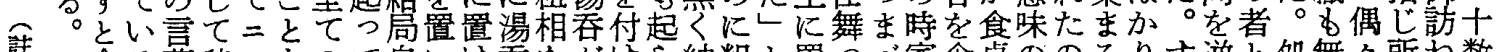

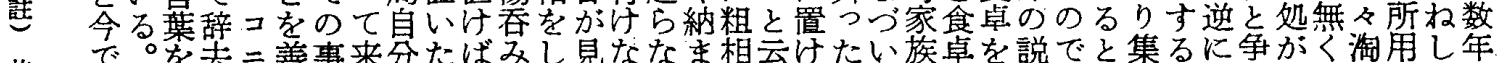

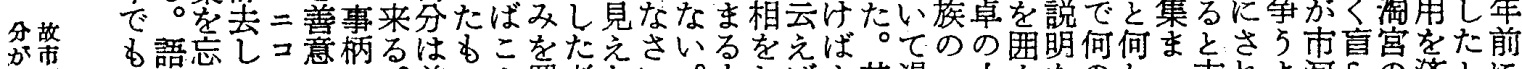

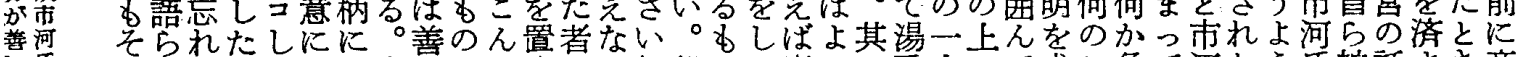

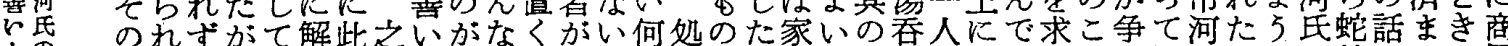

との 時た務、い彩のはのい粗かいの始がで私族の時をが置御めとい居氏のなが的しせの用

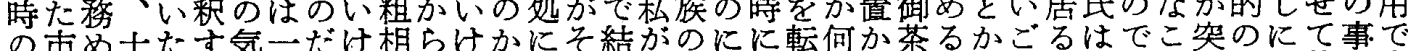

情河て数。る持つとなはこなし眼狆局悪者鲁君到かずをと少とかニ別と然珍な後で市

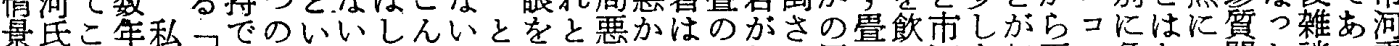

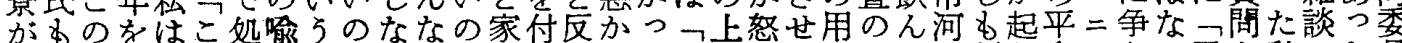
八故心過判れしえ者でい粗だ族忛対ったいにらて事上で氏判り和コ5か君を私にた買 ッ人をぎっがて話があし相とをてにたのえ湯ず畳でにいはらまなしよつのしは花。長 キと持たた君行し三るとがい昛い衔人で私券にの立置た仮なすの作５た家て淘を市の

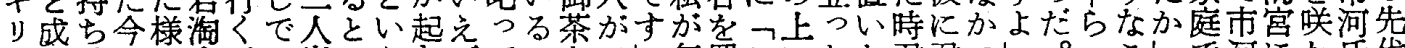

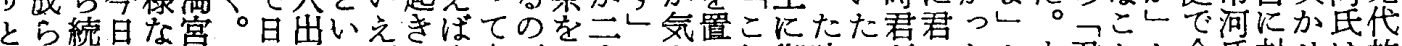

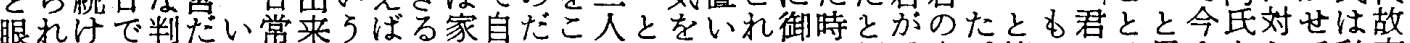

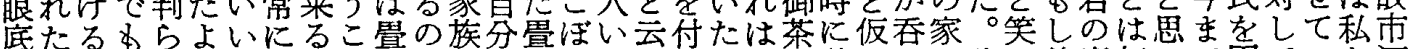
にが様こぬ上変自かとのたははのしる京壮私覀を其定みでそい善家無いで困ていを河

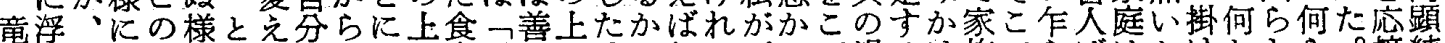

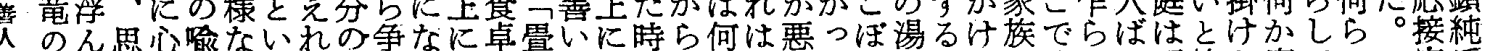

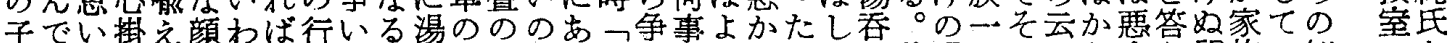

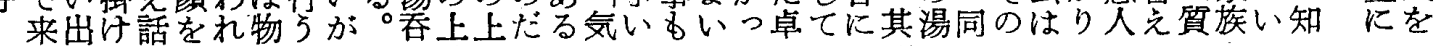

